Рекомендована д. фрармац. наук, проф. Т. Г. Калинюком

УДК 615.451:619:618.19-002

DOI 10.11603/2312-0967.2017.4.8336

\title{
ПІДБІР КІЛЬКІСНОГО СКЛАДУ КОМПОНЕНТІВ ПРИ РОЗРОБЦІ ВЕТЕРИНАРНОГО ПРЕПАРАТУ ДЛЯ ІНТРАЦИСТЕРНАЛЬНОГО ВВЕДЕННЯ
}

\author{
() Ж. М. Полова ${ }^{1}$, Л. Г. Алмакаєва² \\ Національний медичний університет імені О. О. Богомольця ${ }^{1}$, Київ \\ Національний фрармацевтичний університет², Харків \\ zpolova@ukr.net
}

\begin{abstract}
Мета роботи. Розробка якісного складу та підбір оптимального співвідношення компонентів комбінованого ветеринарного препарату для інтрацистернального введення.

Матеріали і методи. Об'єктом дослідження були серії препарату антимікробної дії «Аргоцид», який містить цитрат срібла, D - пантенол та L - аргінін та призначений для лікування і профрілактики субклінічного маститу великої рогатої худоби (BPX). Були вивчені фрізико-хімічні показники стабільності препарата при температурі (25 \pm 2$)^{\circ} \mathrm{C}$ для довгострокових випробувань та при температурі $(40 \pm 2){ }^{\circ} \mathrm{C}$ для прискорених. Визначали наступні параметри відповідно до вимог Державної Фармакопеї України: кількісний вміст діючих речовин, зовнішній вигляд розчину, прозорість, $\mathrm{pH}$.

Результати й обговорення. В результаті дослідження стабільності зразків ветеринарного препарату при зберіганні з наступними співвідношеннями діючих речовин: срібла цитрату - 0,01 г; L - аргініну - 0,52 г; декспантенолу 0,50 г виявлено, що в умовах довгострокового зберігання в зразках спостерігали незмінність їх фрізико-хімічних властивостей протягом лише 6 місяців. Результати прискорених випробувань виявили нестабільність зразків ветеринарного препарату на більш ранніх термінах, яка може бути наслідком деструкції цитрату срібла в досліджуваних зразках. Проведено науково дослідну роботу з метою вивчення стабільності обраної комбінації діючих речовин після зміни їі концентрації в розчині. Дослідження проводили, аналізуючи результати спостережень за стабільністю зразків, отриманих двома способами. За першим способом отримували ветеринарну лікарську форму, яка являє собою два стерильні розчини - А та В, які змішують перед введенням в одному шприці-тубі для інтрамамарного застосування. Другий спосіб відрізнявся тим, що розчин готували одразу з такими ж концентраціями всіх компонентів, як у змішаному розчині A + B, при цьому зберігалося вибране співвідношення діючих речовин. Висновки. Підібрано оптимальне співвідношення компонентів нового комбінованого інтрамамарного препарату антимікробної дії у вигляді розчину в ампулах, що містить цитрат срібла - 0,005 г, D - пантенол - 0,260 г та $\mathrm{L}$ - аргінін - 0,250 г для лікування та профрілактики субклінічного маститу BPX під умовною назвою «Аргоцид», що є стабільним при зберіганні протягом 12 місяців.
\end{abstract}

Ключові слова: ветеринарний препарат; інтрацистернальне введення; стабільність; цитрат срібла.

Вступ. На сьогодні перед ветеринарною фрармацевтичною наукою стоїть завдання розробки і впровадження в практику більш сучасних методів і засобів профрілактики та лікування хвороб сільськогосподарських тварин, а також пошуку ефективних ветеринарних препаратів. Сучасна технологія ведення молочного скотарства зумовлює напружене фрункціонування молочної залози корів протягом лактації, що робить її нестійкою до негативного впливу фракторів зовнішнього середовища, що, в свою чергу, спричиняє у великої рогатої худоби (ВРХ) розвиток маститу [1].

В останні роки спостерігається значне збільшення захворюваності тварин у зв'язку зі зниженням ефективності традиційних методів терапії, зростанням стійкості патогенних мікроорганізмів до лікарських засобів, які застосовують спеціалісти ветеринарної медицини [2].
Основною метою лікувальної терапії при маститах BPX $€$ усунення запального процесу в тканинах вимені та відновлення молочної продуктивності. Оскільки універсальних прийомів і засобів лікування при даному захворюванні у ветеринарній практиці не існує, більшість фрахівців вважає, що позитивний ефект при лікуванні корів, хворих на мастити, можна отримати тільки, якщо лікування проводити комплексно з урахуванням форми і часу перебігу запального процесу, причини, що його спричинила, біологічних особливостей збудника, його чутливості до застосовуваних антимікробних засобів, а також загального стану організму тварини [3].

Впродовж багатьох років застосовують багато способів лікування і лікарських засобів, але досі не розроблена універсальна схема лікування, яка скорочувала б час лікування і витрати [4]. Розробка плану

ISSN 2312-0967. Pharmaceutical review. 2017. № 4 
Фармацевтична технологія, біофармація, гомеопатія Pharmaceutical technology, biopharmacy, homeopathy

запобіжних заходів щодо інфрекцій, що сприятимуть зниженню потреби у антибіотиках, є дуже актуальним завданням. Відомо, що запобігти захворюванню завжди краще, ніж лікувати. У продуктивних тварин антибіотикотерапія повинна бути лише частиною, але не замінником комплексної програми контролю інфекційних захворювань у стаді. Такі програми передбачають дотримання гігієнічних норм, проведення заходів із біобезпеки, дезінфекції, за потреби внесення змін до схеми утримання, годівлі, вакцинації тощо. Обережне і обґрунтоване застосування антибіотиків - запорука збереження їх ефрективності [5, 6].

Запропоновано новий комбінований інтрамамарний препарат антимікробної дії у вигляді водного розчину, що містить цитрат срібла, D - пантенол та $\mathrm{L}$ - аргінін для лікування та профрілактики субклінічного маститу BPX.

Метою нашого дослідження $€$ розробка якісного складу та підбір оптимального співвідношення компонентів комбінованого ветеринарного препарату для інтрацистернального введення.

Матеріали і методи. Як об'єкти дослідження були напрацьовані серії препарату різного складу в скляних ампулах оранжевого скла (Soda Lime Silica glass) об'ємом 10 мл (виробник - Shandong Pharmaceutical Glass Co., Ltd. (Китай) в асептичних умовах науководослідної лабораторії парентеральних та оральних рідких лікарських засобів при Національному фрармацевтичному університеті (м. Харків). Використані діючі речовини - срібла цитрат (виробник ТОВ "Наноматеріали і нанотехнології”, м. Київ); D - пантенол USP (виробник - BASF, Німеччина); L - аргініну гідрохлорид (виробник - Tianjin Tiyanyan Pharmaceutical Co.Ltd (Китай) та допоміжні речовини: стабілізатор повідон, розчинник - вода для ін'єкцій.

Кількісний вміст іонів срібла у ветеринарному препараті (ВП) визначали тіоціанометрично [7]. Кількісне визначення декспантенолу проводили методом рідинної хроматографії згідно з методикою Державної Фармакопеї України (ДФУ) 2.0 «2.2.29. Рідинна хроматографрія». Потенціометричне визначення рН експериментальних зразків проводили за методикою ДФУ 2.0 , п. 2.2.3, стор. 51-53. [8]. Вимірювання проводили за допомогою $\mathrm{pH}$-метра «Seven Easy $\mathrm{pH}$ у комплекті з електродами виробництва фрірми «Mettler Toledo» (Китай) (зав. № 1231145668). Усі виміри проводили при температурі в діапазоні від 20 до $25^{\circ} \mathrm{C}$. Прилад калібрували за допомогою стандартних буферних розчинів.

Визначення прозорості препарату проводили відповідно до методики ДФУ 2.0 « 2.2.1. Визначення прозорості і ступеня каламутності рідин», стор. 47.

Статистичну обробку результатів експериментальних даних проводили відповідно до вимог статті ДФУ 2.0 «5.3.N.1. Статистичний аналіз результатів хімічного експерименту» [8].

Результати й обговорення. В результаті попередньо проведених досліджень було розроблено якіс- ний склад та співвідношення компонентів антимікробного ветеринарного препарату для інтрамамарного введення під умовною назвою «Аргоцид», що складається з трьох активних фрармацевтичних інгредієнтів (срібла цитрат, декспантенол, L - аргінін) та допоміжних речовин (повідон, вода для ін'єкцій) у наступних кількостях:

срібла цитрату - 0,01 г

L - аргініну - 0,52 г

декспантенолу - 0,50 г

повідону - 1,50 г

води для ін'єкцій - до 10 мл

Отримано зразки препарату, що являють собою прозорі розчини з прийнятним рівнем рН $(6,63-6,67)$, 3 кількісним вмістом діючих речовин, у відповідних регульованих для них межах. Напрацьовано 3 серії препарату з обраним співвідношенням компонентів, в ампулах, з метою дослідження стабільності зразків ветеринарного препарату при зберіганні. Зразки кожної серії поділено на дві частини і закладені на зберігання в умовах, які правилами GMP приймають для «загального випадку». Це температура $(25 \pm 2){ }^{\circ} \mathrm{C}$ для довгострокових випробувань (серії 1.1, 2.1, 3.1) та температура $(40 \pm 2){ }^{\circ} \mathrm{C}$ для прискорених (серії 1.2 , 2.2, 3.2) [9].

Результати контролю серій в процесі зберігання в зазначених умовах представлені в таблицях 1 і 2.

3 даних таблиці 1 видно, що в умовах довгострокового зберігання в зразках спостерігалася незмінність їх фрізико-хімічних властивостей протягом 6 місяців, але до дев'ятого місяця в ампулах виявлялася суспензія і розчин набував сіруватого відтінку. Подальші спостереження не проводили.

В умовах прискорених випробувань при температурі зберігання $(40 \pm 2){ }^{\circ} \mathrm{C}$ (табл. 2) аналогічні зміни спостерігалися вже після 3 місяців зберігання, а до 6-го місяця в ампулах випав осад чорного кольору.

Кількісний вміст діючих речовин $L$ - аргініну і декспантенолу відповідав критеріям прийнятності. Кількісний вміст іонів срібла при обох температурних режимах виявив «значні зміни» на різних термінах зберігання. Ці зміни $є$ наслідком деструкції цитрату срібла в досліджуваних зразках.

Отримані дані спостережень виявили, що стабільність зразків зберігалася протягом 6 місяців довгострокового зберігання.

Результати прискорених випробувань виявили нестабільність ветеринарного препарату на більш ранніх термінах, яка може бути пов'язана з розкладанням однієї з діючих речовин, срібла цитрату, за рахунок збільшення швидкості його деструкції при підвищеній температурі, що призводить до випадання осаду металевого срібла. Ці дані, як додаток до результатів довгострокових досліджень, свідчать про недостатню стабільності зразків препарату «Аргоцид» наведеного складу, що не дозволило встановити передбачуваний термін зберігання не менше 12 місяців.

ISSN 2312-0967. Фармацевтичний часопис. 2017. № 4 
Фармацевтична технологія, біофармація, гомеопатія Pharmaceutical technology, biopharmacy, homeopathy

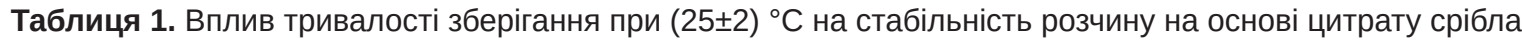

\begin{tabular}{|c|c|c|c|c|c|c|c|}
\hline \multirow{3}{*}{$\begin{array}{l}\text { № } \\
\text { cepiï }\end{array}$} & \multirow{3}{*}{$\begin{array}{l}\text { Тривалість } \\
\text { зберігання, } \\
\text { міс. }\end{array}$} & \multicolumn{6}{|c|}{ Показники якості } \\
\hline & & \multirow{2}{*}{$\begin{array}{c}\text { опис (прозора } \\
\text { рідина світло- } \\
\text { жовтого кольору) }\end{array}$} & \multirow{2}{*}{$\begin{array}{c}\text { прозорість } \\
\text { (повинен бути } \\
\text { прозорий) }\end{array}$} & \multirow[b]{2}{*}{$\begin{array}{c}\mathrm{pH} \\
(6,0-7,0)\end{array}$} & \multicolumn{3}{|c|}{ кількісний вміст, мг/мл } \\
\hline & & & & & $\begin{array}{l}\mathrm{L}-\text { аргінін } \\
(49,4-54,6)\end{array}$ & $\begin{array}{c}\text { декспантенол } \\
(47,5-52,5)\end{array}$ & $\begin{array}{c}\text { іони срібла } \\
\text { (не менше 0,9) }\end{array}$ \\
\hline \multirow[t]{4}{*}{1.1} & 0 & \multirow[t]{3}{*}{ відповідає } & \multirow[t]{3}{*}{ прозорий } & $6,53 \pm 0,1$ & $53,1 \pm 0,2$ & $50,2 \pm 0,2$ & $0,98 \pm 0,01$ \\
\hline & 3 & & & $6,50 \pm 0,1$ & $53,2 \pm 0,1$ & $50,0 \pm 0,3$ & $0,99 \pm 0,01$ \\
\hline & 6 & & & $6,49 \pm 0,1$ & $53,1 \pm 0,3$ & $50,0 \pm 0,2$ & $0,97 \pm 0,02$ \\
\hline & 9 & $\begin{array}{c}\text { непрозора рідина } \\
\text { світло-жовтого } \\
\text { кольору з сірим } \\
\text { відтінком }\end{array}$ & завис & $6,21 \pm 0,2$ & $53,1 \pm 0,2$ & $50,0 \pm 0,1$ & $0,92 \pm 0,03$ \\
\hline \multirow[t]{4}{*}{2.1} & 0 & \multirow[t]{3}{*}{ відповідає } & \multirow[t]{3}{*}{ прозорий } & $6,50 \pm 0,3$ & $53,3 \pm 0,2$ & $49,8 \pm 0,2$ & $0,99 \pm 0,01$ \\
\hline & 3 & & & $6,51 \pm 0,1$ & $53,2 \pm 0,1$ & $49,5 \pm 0,2$ & $0,97 \pm 0,01$ \\
\hline & 6 & & & $6,49 \pm 0,1$ & $53,3 \pm 0,3$ & $50,1 \pm 0,1$ & $0,95 \pm 0,02$ \\
\hline & 9 & $\begin{array}{c}\text { непрозора рідина } \\
\text { світло-жовтого } \\
\text { кольору з сірим } \\
\text { відтінком }\end{array}$ & завис & $6,25 \pm 0,2$ & $53,2 \pm 0,1$ & $49,9 \pm 0,1$ & $0,94 \pm 0,01$ \\
\hline \multirow[t]{4}{*}{3.1} & 0 & \multirow[t]{3}{*}{ відповідає } & \multirow[t]{3}{*}{ прозорий } & $6,47 \pm 0,2$ & $52,5 \pm 0,2$ & $50,5 \pm 0,2$ & $0,98 \pm 0,01$ \\
\hline & 3 & & & $6,49 \pm 0,1$ & $52,4 \pm 0,1$ & $50,0 \pm 0,3$ & $0,99 \pm 0,01$ \\
\hline & 6 & & & $6,45 \pm 0,1$ & $52,0 \pm 0,3$ & $50,1 \pm 0,1$ & $0,97 \pm 0,02$ \\
\hline & 9 & $\begin{array}{c}\text { непрозора рідина } \\
\text { світло-жовтого } \\
\text { кольору з сірим } \\
\text { відтінком }\end{array}$ & завис & $6,23 \pm 0,1$ & $52,0 \pm 0,2$ & $50,0 \pm 0,1$ & $0,95 \pm 0,03$ \\
\hline
\end{tabular}

Примітка. $\mathrm{P} \pm 95 \%, \mathrm{n}=5$.

Таблиця 2. Вплив тривалості зберігання при $40 \pm 2{ }^{\circ} \mathrm{C}$ на стабільність розчину на основі цитрату срібла

\begin{tabular}{|c|c|c|c|c|c|c|c|}
\hline \multirow{3}{*}{$\begin{array}{l}\text { № } \\
\text { cepiï }\end{array}$} & \multirow{3}{*}{$\begin{array}{c}\text { Тривалість } \\
\text { зберігання, } \\
\text { міс. }\end{array}$} & \multicolumn{5}{|c|}{ Показники якості } & \\
\hline & & \multirow{2}{*}{$\begin{array}{c}\text { опис (прозора } \\
\text { рідина світло- } \\
\text { жовтого кольору) }\end{array}$} & \multirow{2}{*}{$\begin{array}{c}\text { прозорість } \\
\text { (повинен бути } \\
\text { прозорий) }\end{array}$} & \multirow{2}{*}{$\begin{array}{c}\mathrm{pH} \\
(6,0-7,0)\end{array}$} & \multicolumn{3}{|c|}{ кількісний вміст, мг/мл } \\
\hline & & & & & $\begin{array}{l}\mathrm{L}-\text { аргінін } \\
(49,4-54,6)\end{array}$ & $\begin{array}{c}\text { декспантенол } \\
(47,5-52,5)\end{array}$ & $\begin{array}{c}\text { іони срібла } \\
\text { (не менше 0,9) }\end{array}$ \\
\hline \multirow[t]{3}{*}{1.2} & 0 & відповідає & прозорий & $6,50 \pm 0,1$ & $53,1 \pm 0,2$ & $50,2 \pm 0,1$ & $0,98 \pm 0,01$ \\
\hline & 3 & $\begin{array}{l}\text { непрозора рідина } \\
\text { з сірим відтінком }\end{array}$ & завис & $6,12 \pm 0,1$ & $53,2 \pm 0,1$ & $50,0 \pm 0,3$ & $0,90 \pm 0,01$ \\
\hline & 6 & $\begin{array}{c}\text { непрозора рідина } \\
\text { з чорним осадом }\end{array}$ & осад & $5,76 \pm 0,1$ & $53,1 \pm 0,3$ & $50,0 \pm 0,2$ & $0,85 \pm 0,01$ \\
\hline \multirow[t]{3}{*}{2.2} & 0 & відповідає & прозорий & $6,23 \pm 0,3$ & $53,3 \pm 0,2$ & $49,8 \pm 0,2$ & $0,97 \pm 0,01$ \\
\hline & 3 & $\begin{array}{c}\text { непрозора рідина } \\
\text { з сірим відтінком }\end{array}$ & завис & $6,15 \pm 0,1$ & $53,2 \pm 0,1$ & $49,5 \pm 0,1$ & $0,91 \pm 0,01$ \\
\hline & 6 & $\begin{array}{c}\text { непрозора рідина } \\
3 \text { чорним осадом }\end{array}$ & осад & $5,78 \pm 0,1$ & $53,3 \pm 0,3$ & $50,1 \pm 0,1$ & $0,84 \pm 0,02$ \\
\hline \multirow[t]{3}{*}{3.2} & 0 & відповідає & прозорий & $6,23 \pm 0,3$ & $52,5 \pm 0,2$ & $50,5 \pm 0,2$ & $0,98 \pm 0,02$ \\
\hline & 3 & $\begin{array}{l}\text { непрозора рідина } \\
\text { з сірим відтінком }\end{array}$ & завис & $6,14 \pm 0,1$ & $52,4 \pm 0,1$ & $50,0 \pm 0,1$ & $0,94 \pm 0,01$ \\
\hline & 6 & $\begin{array}{c}\text { непрозора рідина } \\
3 \text { чорним осадом }\end{array}$ & осад & $5,72 \pm 0,1$ & $52,0 \pm 0,3$ & $50,1 \pm 0,1$ & $0,85 \pm 0,02$ \\
\hline
\end{tabular}

Примітка. $\mathrm{P} \pm 95 \%, \mathrm{n}=5$.

ISSN 2312-0967. Pharmaceutical review. 2017. № 4 
Фармацевтична технологія, біофармація, гомеопатія Pharmaceutical technology, biopharmacy, homeopathy

Тому перед нами постало завдання підвищення стабільності досліджуваної композиції діючих та допоміжних речовин. 3 цією метою були розглянуті наступні можливі напрямки підвищення стабільності:

- введення додаткових допоміжних речовин 3 метою стабілізації розчину;

- використання різних технологічних прийомів для підвищення стабільності, таких як підбір оптимального порядку введення інгредієнтів у розчин, використання інертних газів для запобігання деструктивному впливу кисню повітря, захист від дії світла, зменшення концентрації нестабільних компонентів при збереженні їх дозування.

Заходи для зменшення або запобігання ризику для якості не повинні призводити до внесення нових ризиків у систему або до збільшення важливості інших існуючих ризиків $[10,11]$.

Шлях підвищення стабільності за рахунок введення додаткових стабілізаторів нами був оцінений як менш прийнятний, оскільки може призвести до утворення побічних продуктів, виникнення додаткових труднощів при приготуванні розчину та його аналізі, а також до подорожчання препарату, адже економічна доступність $€$ важливим чинником доцільності розробки препаратів для застосування у ветеринарії.

Роботи в напрямку використання різних зазначених технологічних прийомів без зміни складу і концентрації компонентів результату не дали - термін придатності зразків з різним порядком введення інгредієнтів, при використанні газового захисту на операціях приготування розчину, наповнення та запаювання, а також при приготуванні розчину в зачохленому обладнанні (захист від дії світла) не перевищував 6 місяців.

Наступним етапом була науково-дослідна робота з метою вивчення стабільності обраної комбінації діючих речовин після зміни її концентрації в розчині. Дослідження проводили, аналізуючи результати спостережень за стабільністю зразків, отриманих двома способами
За першим способом отримували ветеринарну лікарську фрорму, яка являє собою два стерильні розчини, які змішують перед введенням в одному шприці-тубі для інтрамамарного застосування. В одну ємність (ампулу) поміщали розчин срібла цитрату стерильний, стабілізований повідоном - ампула А. До складу другого розчину входили декспантенол і L - аргінін - ампула B, в дозах, наведених у таблиці 3.

Такий поділ компонентів зумовлений їх кислотною або лужною природою. В ампулі А створені оптимальні умови для срібла цитрату, згідно з його властивостями. Це - кисле середовище (pH 2,5, згідно 3 експериментальними даними) і наявність стабілізатора в оптимальній концентрації. В ампулі В - сполуки, що мають лужні властивості. Розчин декспантенолу $5 \%$ має $\mathrm{pH}$ не менше 10,5 та $\mathrm{pH} 5 \%$ розчину L - аргініну знаходиться в інтервалі 10,5-12,0. Таким чином, вони цілком сумісні в одному розчині і можуть бути стабільні при довгостроковому зберіганні.

Подібний спосіб поділу розчину на дві частини, що змішуються перед введенням, відомий і широко використовується в випадках, коли до складу входять компоненти, домогтися стабільності яких при сумісній присутності в розчині не є можливим. Це, наприклад, розчин для ін'єкцій «Дона», виробництва фрірми «Роттафрарм С.п.А. / Біологічі Італія Лабораторіз С.Р.Л.», Італія. Являє собою комплект з двох ампул, вміст яких змішують перед введенням в одному шприці [12].

Вивчено показники якості зразків ампул А і В, а також змішаного розчину обох ампул в одному шприцітубі, результати відображені у таблиці 4.

Як видно з даних таблиці 4, змішаний розчин 3 ампул A і В має прийнятний для інтрамамарного введення рівень $\mathrm{pH}$, він прозорий, кількісний вміст діючих речовин знаходиться в очікуваних інтервалах. Розчин також не змінює своїх фрізико-хімічних характеристик протягом періоду, необхідного для прове-

Таблиця 3. Кількісний склад розчинів А і В в ампулах та змішаного розчину

\begin{tabular}{|c|c|c|c|c|}
\hline \multirow{2}{*}{ Об'єкт } & \multirow{2}{*}{ Компонентний склад } & \multicolumn{3}{|c|}{ Вміст } \\
\hline & & 10 мл & 20 мл & мг/мл \\
\hline \multirow[t]{2}{*}{ Ампула А } & Повідон & 1,500 г & & 150,0 \\
\hline & $\begin{array}{l}\text { Розчин срібла цитрату 0,1%, } \\
\text { в т.ч. іонів срібла }\end{array}$ & $\begin{array}{c}5 \text { мл } \\
0,010 \text { г }\end{array}$ & & 1,0 \\
\hline \multirow[t]{3}{*}{ Ампула B } & L- аргінін & 0,520 г & & 52,0 \\
\hline & Декспантенол & 0,500 г & & 50,0 \\
\hline & Вода для ін'єкцій & до 10 мл & & - \\
\hline \multirow{5}{*}{$\begin{array}{l}\text { Змішаний } \\
\text { розчин }\end{array}$} & Повідон & & 1,500 г & 75,0 \\
\hline & Срібло (у вигляді цитрату) & & 0,010 г & 0,5 \\
\hline & L- аргінін & & 0,520 г & 26,0 \\
\hline & Декспантенол & & 0,500 г & 25,0 \\
\hline & Вода для ін'єкцій & & до 20 мл & - \\
\hline
\end{tabular}

ISSN 2312-0967. Фармацевтичний часопис. 2017. № 4 
Фармацевтична технологія, біофармація, гомеопатія Pharmaceutical technology, biopharmacy, homeopathy

Таблиця 4. Дослідження показників якості розчинів в ампулах А і В та змішаного розчину

\begin{tabular}{|c|c|c|c|c|c|c|}
\hline \multirow{3}{*}{$\begin{array}{c}\text { Об'єкт } \\
\text { дослідження }\end{array}$} & \multicolumn{6}{|c|}{ Показники якості } \\
\hline & \multicolumn{3}{|c|}{ кількісний вміст } & \multirow{2}{*}{$\begin{array}{c}\text { опис (прозора } \\
\text { рідина світло- } \\
\text { жовтого кольору) }\end{array}$} & \multirow{2}{*}{$\begin{array}{c}\text { прозорість } \\
\text { (повинен } \\
\text { бути } \\
\text { прозорий) }\end{array}$} & \multirow[b]{2}{*}{$\begin{array}{c}\mathrm{pH} \\
(6,0-7,0)\end{array}$} \\
\hline & найменування & $\begin{array}{c}\text { критерії } \\
\text { прийнятності, } \\
\text { мг/мл }\end{array}$ & результат & & & \\
\hline Ампула A & іони срібла & не менше 0,9 & $0,98 \pm 0,01$ & $\begin{array}{c}\text { прозора рідина } \\
\text { світло-жовтого } \\
\text { кольору }\end{array}$ & прозорий & $2,37 \pm 0,01$ \\
\hline \multirow[t]{2}{*}{ Ампула В } & L- аргінін & $49,4-54,6$ & $52,7 \pm 0,1$ & \multirow{2}{*}{$\begin{array}{c}\text { прозора рідина } \\
\text { світло-жовтого } \\
\text { кольору }\end{array}$} & \multirow[t]{2}{*}{ прозорий } & \multirow[t]{2}{*}{$11,05 \pm 0,01$} \\
\hline & декспантенол & $47,5-52,5$ & $50,3 \pm 0,2$ & & & \\
\hline \multirow{3}{*}{$\begin{array}{c}\mathrm{A}+\mathrm{B} \\
\text { (змішаний } \\
\text { розчин) }\end{array}$} & іони срібла & не менше 0,45 & $0,49 \pm 0,01$ & \multirow{3}{*}{$\begin{array}{c}\text { прозора рідина } \\
\text { світло-жовтого } \\
\text { кольору }\end{array}$} & \multirow[t]{3}{*}{ прозорий } & \multirow[t]{3}{*}{$6,48 \pm 0,02$} \\
\hline & L- аргінін & $24,7-27,3$ & $24,3 \pm 0,2$ & & & \\
\hline & декспантенол & $23,7-26,3$ & $25,1 \pm 0,1$ & & & \\
\hline
\end{tabular}

Примітка. $\mathrm{P} \pm 95 \%, \mathrm{n}=5$.

дення маніпуляції для введення розчину в цистерни вимені ВРХ (спостереження тривало понад 6 год).

Як видно з даних таблиці 3, кількісний вміст діючих та допоміжних речовин у змішаному розчині у відсотковому вираженні вдвічі нижчий, ніж у зразках, досліджених в таблиці 1 та 2, однак разова доза композиції діючих речовин залишилася незмінною. Об'єм отриманого розчину для введення в цистерну вимені (20 мл) є також прийнятним, що підтверджується результатами аналізу асортименту ветеринарних лікарських засобів для інтрамамарного застосування [13].

Ми брали до уваги відомий фракт, що скло ампули не індиферентне до розчинів, особливо у яких рівень $\mathrm{pH}$ значно відрізняється від нейтрального. У таких випадках, а також залежно від хімічної стійкості марки скла контейнера може відбуватися процес вилужнювання або розчинення верхнього шару скла. Лужні розчини, впливаючи на поверхню скла, розчиняють і змивають поверхневий шар, розриваючи кисневокремнієві зв'язки. Це призводить до відшарування і переходу верхнього шару скла в розчин, що викликає появу механічних включень [14, 15].

Вилужнювання зі скла компонентів і / або їх гідроліз може призводити як до збільшення, так і до зменшення величини $\mathrm{pH}$ розчину. Це призводить до змін властивостей лікарських речовин, в основі яких лежать різні хімічні процеси: гідроліз, окислення, відновлення, омилення, декарбоксилювання, ізомеризація тощо. 3 часом цей процес може сповільнюватися і навіть припинятися через утворення на поверхні скла кремнеземистої плівки [16].

Тому були спрогнозовані ризики для стабільності запропонованих складів через деструкції внутрішнього шару скла ампули, викликаної кислим або лужним рівнем рН розчинів А і В. Це може призвести до утворення механічних включень, а також бути причиною деструкції або зміни властивостей діючих речовин або розчинів А і В. У разі виникнення цих змін якість отриманого ветеринарного препарату не буде відповідати регламентованим критеріям [17].

Для спостереження за стабільністю препарату були напрацьовані три серії зразків складу А в ампулах скляних і три серії зразків складу В в аналогічних контейнерах. Також вважали за доцільне приготувати розчини за другим способом, який відрізнявся тим, що розчин готували одразу з такими ж концентраціями всіх компонентів, як у змішаному розчині $A+B$, при цьому зберігалося вибране співвідношення діючих речовин, наведене у таблиці 4.

Передбачуваний ризик для стабільності розчину в цьому випадку також присутній, оскільки в попередніх дослідженнях виявлено нестабільність лікарського препарату з обраним співвідношенням діючих речовин при зберіганні більше 6 місяців (таблиця 1 та 2). Однак концентрація компонентів, зазначена в таблиці 1 та 2, перевищувала концентрацію діючих речовин у розчині, приготованому за другим способом вдвічі.

Ідентифрікація ризику призводить до висновку, що основна причина нестабільності - це деструкція однієї 3 діючих речовин, срібла цитрату, оскільки продуктом деструкції є срібло, що утворює осад чорного кольору. При цьому інші компоненти розчину не змінювали своїх фрізико-хімічних властивостей. Нестабільність цитрату срібла зумовлена введенням у вихідний 0,1 \% розчин досить великої кількості компонентів, які дисоціюють, протонуються, солюбілізуються, беруть участь в інших процесах, що перебігають в розчині, при цьому порушується співвідношення срібла цитрату, молекул води та іонів, на які вона дисоціює, що призводить до незворотного порушення рівноваги в системі.

Заходи щодо зниження ризику були спрямовані на збереження рівноваги в розчині срібла цитрату в присутності інших компонентів за рахунок збільшення водної фрази, але не перевищуючи встановлений (прийнятний) рівень.

ISSN 2312-0967. Pharmaceutical review. 2017. № 4 
Фармацевтична технологія, біофармація, гомеопатія Pharmaceutical technology, biopharmacy, homeopathy

Зразки, приготовані за першим способом (розчини А і В в ампулах), а також приготовані за другим способом, були одночасно закладені на зберігання для спостереження за стабільністю. Результати контролю серій, приготованих за першим і другим способом, в процесі зберігання при температурі $(25 \pm 2){ }^{\circ} \mathrm{C}$ (довгострокові випробування) і температурі $(40 \pm 2)^{\circ} \mathrm{C}$ (прискорені випробування) представлені в таблицях 5 та 6.

Порівняльний аналіз результатів спостереження за стабільністю зразків, приготованих двома способами, дозволив зробити висновок про те, що всі зразки, що зберігалися при температурі $(25 \pm 2){ }^{\circ} \mathrm{C}$, показали стабільність протягом 12 місяців зберігання. Фі- зико-хімічні показники якості розчинів на всіх контрольних етапах експерименту перебували в допустимих межах. Кількісний вміст діючих речовин був у межах помилки вимірювання.

Слід зазначити, що зразки розчину А при зберіганні при температурі $(40 \pm 2){ }^{\circ} \mathrm{C}$ після 9 місяців проявили нестабільність. Зразки, приготовані за другою технологією, проявили стабільність протягом 12 місяців зберігання.

Ці дані, наведені в таблиці 6, ми врахували як доповнення до результатів довгострокових досліджень, яке може свідчити про недостатню стабільності досліджуваного складу при стресових умовах. Але також враховували, що ці результати не завжди дозво-

Таблиця 5. Вплив тривалості зберігання при $(25 \pm 2){ }^{\circ} \mathrm{C}$ на стабільність експериментальних зразків препарату «Аргоцид»

\begin{tabular}{|c|c|c|c|c|c|c|c|}
\hline \multirow{3}{*}{$\begin{array}{c}\text { Об'єкт } \\
\text { контролю }\end{array}$} & \multirow{3}{*}{$\begin{array}{c}\text { Тривалість } \\
\text { зберігання, } \\
\text { міс. }\end{array}$} & \multicolumn{6}{|c|}{ Показники якості } \\
\hline & & \multirow{2}{*}{ опис } & \multirow{2}{*}{ прозорість } & \multirow{2}{*}{$\mathrm{pH}$} & \multicolumn{3}{|c|}{ кількісний вміст, мг/мл } \\
\hline & & & & & іони срібла & L-аргінін & декспантенол \\
\hline \multirow[t]{6}{*}{$\begin{array}{c}\text { Ампули } 3 \\
\text { розчином } \\
\text { А }\end{array}$} & норматив & $\begin{array}{c}\text { прозора } \\
\text { рідина } \\
\text { світло- } \\
\text { жовтого } \\
\text { кольору } \\
\end{array}$ & $\begin{array}{c}\text { повинен } \\
\text { бути } \\
\text { прозорим }\end{array}$ & $2,5-6,7$ & $\begin{array}{c}\text { не менше } \\
0,9\end{array}$ & - & - \\
\hline & 0 & відповідає & прозорий & $2,53 \pm 0,03$ & $0,99 \pm 0,01$ & - & - \\
\hline & 3 & відповідає & прозорий & $2,53 \pm 0,03$ & $0,99 \pm 0,01$ & - & - \\
\hline & 6 & відповідає & прозорий & $2,53 \pm 0,02$ & $0,98 \pm 0,02$ & - & - \\
\hline & 9 & відповідає & прозорий & $2,54 \pm 0,01$ & $0,98 \pm 0,01$ & - & - \\
\hline & 12 & відповідає & прозорий & $2,53 \pm 0,01$ & $0,98 \pm 0,01$ & - & - \\
\hline \multirow[t]{6}{*}{$\begin{array}{c}\text { Ампули } 3 \\
\text { розчином } \\
\text { В }\end{array}$} & норматив & $\begin{array}{c}\text { прозора } \\
\text { безбарвна } \\
\text { рідина } \\
\end{array}$ & $\begin{array}{c}\text { повинен } \\
\text { бути } \\
\text { прозорим }\end{array}$ & $10,5-12,0$ & - & $49,4-54,6$ & $47,5-52,5$ \\
\hline & 0 & відповідає & прозорий & $11,01 \pm 0,01$ & - & $53,10 \pm 0,11$ & $50,25 \pm 0,01$ \\
\hline & 3 & відповідає & прозорий & $10,98 \pm 0,03$ & - & $53,12 \pm 0,09$ & $50,20 \pm 0,05$ \\
\hline & 6 & відповідає & прозорий & $11,00 \pm 0,02$ & - & $53,10 \pm 0,09$ & $50,23 \pm 0,06$ \\
\hline & 9 & відповідає & прозорий & $11,00 \pm 0,03$ & - & $53,12 \pm 0,10$ & $50,21 \pm 0,04$ \\
\hline & 12 & відповідає & прозорий & $10,98 \pm 0,01$ & - & $53,12 \pm 0,08$ & $50,21 \pm 0,02$ \\
\hline \multirow[t]{6}{*}{$\begin{array}{c}\text { Ампули } 3 \\
\text { розчином } \\
\text { А+В (2 } \\
\text { спосіб } \\
\text { приготу- } \\
\text { вання) }\end{array}$} & норматив & $\begin{array}{c}\text { прозора } \\
\text { рідина } \\
\text { світло- } \\
\text { жовтого } \\
\text { кольору }\end{array}$ & $\begin{array}{c}\text { повинен } \\
\text { бути } \\
\text { прозорим }\end{array}$ & $6,0-7,0$ & $\begin{array}{c}\text { не менше } \\
0,45\end{array}$ & $24,7-27,3$ & $23,7-26,3$ \\
\hline & 0 & $\begin{array}{c}\text { прозора } \\
\text { рідина } \\
\text { світло- } \\
\text { жовтого } \\
\text { кольору }\end{array}$ & прозорий & $6,53 \pm 0,04$ & $0,504 \pm 0,03$ & $26,25 \pm 0,04$ & $25,08 \pm 0,03$ \\
\hline & 3 & відповідає & прозорий & $6,53 \pm 0,04$ & $0,507 \pm 0,02$ & $26,25 \pm 0,03$ & $25,07 \pm 0,01$ \\
\hline & 6 & відповідає & прозорий & $6,52 \pm 0,03$ & $0,506 \pm 0,01$ & $26,23 \pm 0,03$ & $25,08 \pm 0,01$ \\
\hline & 9 & відповідає & прозорий & $6,54 \pm 0,01$ & $0,506 \pm 0,02$ & $26,24 \pm 0,02$ & $25,08 \pm 0,02$ \\
\hline & 12 & відповідає & прозорий & $6,53 \pm 0,02$ & $0,505 \pm 0,01$ & $26,24 \pm 0,01$ & $25,07 \pm 0,01$ \\
\hline
\end{tabular}

Примітка. $\mathrm{P} \pm 95 \%, \mathrm{n}=5$.

ISSN 2312-0967. Фармацевтичний часопис. 2017. № 4 
Фармацевтична технологія, біофармація, гомеопатія Pharmaceutical technology, biopharmacy, homeopathy

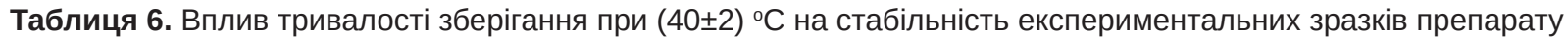
«Аргоцид»

\begin{tabular}{|c|c|c|c|c|c|c|c|}
\hline \multirow{3}{*}{$\begin{array}{c}\text { Об'єкт } \\
\text { контролю }\end{array}$} & \multirow{3}{*}{$\begin{array}{c}\text { Тривалість } \\
\text { зберігання, } \\
\text { міс. }\end{array}$} & \multicolumn{6}{|c|}{ Показники якості } \\
\hline & & \multirow[b]{2}{*}{ опис } & \multirow[b]{2}{*}{ прозорість } & \multirow[b]{2}{*}{$\mathrm{pH}$} & \multicolumn{3}{|c|}{ кількісний вміст, мг/мл } \\
\hline & & & & & $\begin{array}{c}\text { іони } \\
\text { срібла }\end{array}$ & L-аргінін & $\begin{array}{c}\text { декспан- } \\
\text { тенол }\end{array}$ \\
\hline \multirow[t]{6}{*}{$\begin{array}{c}\text { Ампули } 3 \\
\text { розчином } \\
\text { A }\end{array}$} & норматив & $\begin{array}{c}\text { прозора рідина } \\
\text { світло-жовтого } \\
\text { кольору }\end{array}$ & $\begin{array}{l}\text { повинен } \\
\text { бути } \\
\text { прозорим }\end{array}$ & $2,5-6,7$ & $\begin{array}{c}\text { не менше } \\
0,9\end{array}$ & - & - \\
\hline & 0 & відповідає & прозорий & $2,53 \pm 0,03$ & $0,99 \pm 0,01$ & - & - \\
\hline & 3 & відповідає & прозорий & $2,53 \pm 0,03$ & $0,99 \pm 0,01$ & - & - \\
\hline & 6 & відповідає & прозорий & $2,53 \pm 0,02$ & $0,98 \pm 0,02$ & - & - \\
\hline & 9 & $\begin{array}{c}\text { непрозора } \\
\text { сірувата рідина }\end{array}$ & завис & $2,48 \pm 0,01$ & $0,85 \pm 0,01$ & - & - \\
\hline & 12 & $\begin{array}{c}\text { непрозора } \\
\text { сірувата рідина } \\
\text { з осадом }\end{array}$ & осад & $2,45 \pm 0,01$ & $0,80 \pm 0,01$ & - & - \\
\hline \multirow[t]{6}{*}{$\begin{array}{c}\text { Ампули } 3 \\
\text { розчином } \\
\text { В }\end{array}$} & норматив & $\begin{array}{c}\text { прозора } \\
\text { безбарвна } \\
\text { рідина }\end{array}$ & $\begin{array}{l}\text { повинен } \\
\text { бути } \\
\text { прозорим }\end{array}$ & $10,5-12,0$ & - & $49,4-54,6$ & $47,5-52,5$ \\
\hline & 0 & відповідає & прозорий & $11,01 \pm 0,04$ & - & $53,10 \pm 0,09$ & $50,25 \pm 0,01$ \\
\hline & 3 & відповідає & прозорий & $10,99 \pm 0,03$ & - & $53,12 \pm 0,06$ & $50,20 \pm 0,02$ \\
\hline & 6 & відповідає & прозорий & $11,00 \pm 0,02$ & - & $53,10 \pm 0,05$ & $50,23 \pm 0,04$ \\
\hline & 9 & відповідає & прозорий & $11,01 \pm 0,03$ & - & $53,12 \pm 0,02$ & $50,21 \pm 0,02$ \\
\hline & 12 & відповідає & прозорий & $10,98 \pm 0,02$ & - & $53,12 \pm 0,02$ & $50,21 \pm 0,01$ \\
\hline \multirow{6}{*}{$\begin{array}{c}\text { Ампули з } \\
\text { розчином } \\
\text { А+В (2 } \\
\text { спосіб } \\
\text { приготу- } \\
\text { вання) }\end{array}$} & норматив & $\begin{array}{c}\text { прозора рідина } \\
\text { світло-жовтого } \\
\text { кольору } \\
\end{array}$ & $\begin{array}{l}\text { повинен } \\
\text { бути } \\
\text { прозорим } \\
\end{array}$ & $6,0-7,0$ & $\begin{array}{c}\text { Не менше } \\
0,45\end{array}$ & $24,7-27,3$ & $23,7-26,3$ \\
\hline & 0 & $\begin{array}{c}\text { прозора рідина } \\
\text { світло-жовтого } \\
\text { кольору } \\
\end{array}$ & прозорий & $6,53 \pm 0,04$ & $0,504 \pm 0,03$ & $26,25 \pm 0,04$ & $25,08 \pm 0,03$ \\
\hline & 3 & відповідає & прозорий & $6,53 \pm 0,03$ & $0,507 \pm 0,01$ & $26,25 \pm 0,02$ & $25,07 \pm 0,05$ \\
\hline & 6 & відповідає & прозорий & $6,52 \pm 0,02$ & $0,506 \pm 0,02$ & $26,23 \pm 0,04$ & $25,08 \pm 0,02$ \\
\hline & 9 & відповідає & прозорий & $6,54 \pm 0,01$ & $0,506 \pm 0,01$ & $26,24 \pm 0,03$ & $25,08 \pm 0,02$ \\
\hline & 12 & відповідає & прозорий & $6,53 \pm 0,02$ & $0,505 \pm 0,01$ & $26,24 \pm 0,01$ & $25,07 \pm 0,01$ \\
\hline
\end{tabular}

Примітка. $\mathrm{P} \pm 95 \%, \mathrm{n}=5$.

ляють прогнозувати зміни, які виникають або не виникають при довгострокових випробуваннях.

Тому з огляду на позитивні результати контролю зразків розчинів, наведених у таблицях 5 та 6, зроблено висновок, що зразки розчинів, приготовані за двома технологіями, витримують зберігання протягом 12 місяців. При цьому на підставі аналізу даних таблиці 6 кращим способом було прийнято другий. Цей спосіб також більш зручний у виробництві, крім того, готовий продукт придатний до використання і не вимагає проведення додаткових маніпуляцій перед застосуванням.

На основі вивчення літературних даних, фрізико-хімічних властивостей діючих речовин срібла цитрату, L - аргініну, декспантенолу та допоміжної речовини повідону, а також на основі спостережень за їхньою стабільністю в складі розчину комбінованого препарату був підібраний оптимальний склад препарату для інтрамамарного введення для ветеринарії в ампулах по 10 мл наступного складу:

срібла цитрату - 0,005

L- аргініну - 0,260

декспантенолу - 0,250

повідону - 1,50

води для ін'єкцій - до 10 мл

Висновки. 1. У результаті дослідження стабільності зразків ветеринарного препарату при зберіганні з наступними співвідношеннями діючих речовин: срібла цитрату - 0,01 г; L - аргініну - 0,52 г; декспантенолу - 0,50 г виявлено, що в умовах довгострокового зберігання в зразках спостерігалася незмінність їх фрізико-хімічних властивостей протягом 6 місяців. Ре-

ISSN 2312-0967. Pharmaceutical review. 2017. № 4 
Фармацевтична технологія, біофармація, гомеопатія Pharmaceutical technology, biopharmacy, homeopathy

зультати прискорених випробувань виявили нестабільність зразків ветеринарного препарату на більш ранніх термінах, яка може бути наслідком деструкції цитрату срібла в досліджуваних зразках.

2. Була проведена науково-дослідна робота з метою вивчення стабільності обраної комбінації діючих речовин після зміни її концентрації в розчині. Дослідження проводили, аналізуючи результати спостережень за стабільністю зразків, отриманих двома способами. За першим способом отримували ветеринарну лікарську фрорму, яка являє собою два стерильні розчини - A та $B$, що змішуються перед введенням в одному шприці-тубі для інтрамамарного застосування. Другий спосіб відрізнявся тим, що розчин готували одразу з такими ж концентраціями всіх компонентів, як у змішаному розчині $\mathrm{A}+\mathrm{B}$, при цьому зберігалося вибране співвідношення діючих речовин.

3. 3 огляду на позитивні результати контролю зразків розчинів на стабільність зроблено висновок, що зразки ветеринарного препарату «Аргоцид», приготовані за двома технологіями, витримують зберігання протягом 12 місяців.

4. Підібрано оптимальне співвідношення компонентів нового комбінованого інтрамамарного препарату антимікробної дії у вигляді водного розчину в ампулах, що містить цитрат срібла - 0,005 г, D - пантенол - 0,260 г та L - аргінін - 0,250 г для лікування та профрілактики субклінічного маститу ВРX під умовною назвою «Аргоцид».

\title{
ПОДБОР КОЛИЧЕСТВЕННОГО СОСТАВА КОМПОНЕНТОВ ПРИ РАЗРАБОТКЕ ВЕТЕРИНАРНОГО ПРЕПАРАТА ДЛЯ ИНТРАЦИСТЕРНАЛЬНОГО ВВЕДЕНИЯ
}

\author{
Ж. Н. Полова ${ }^{1}$, Л. Г. Алмакаева ${ }^{2}$ \\ Национальный медицинский университет имени А. А. Богомольца ${ }^{1}$, Киев \\ Национальный фрармацевтический университет², Харьков \\ zpolova@ukr.net
}

Цель работы. Разработка качественного состава и подбор оптимального соотношения компонентов комбинированного ветеринарного препарата для интрацистернального введения.

Материалы и методы. Объектом исследования были серии препарата антимикробного действия «Аргоцид», который содержит цитрат серебра, D-пантенол и L-аргинин и предназначен для лечения и профилактики субклинического мастита крупного рогатого скота (КРС). Были изучены фризико-химические показатели стабильности препарата при температуре $(25 \pm 2){ }^{\circ} \mathrm{C}$ для долгосрочных испытаний и при температуре $(40 \pm 2){ }^{\circ} \mathrm{C}$ для ускоренных. Определяли следующие параметры в соответствии с требованиями Государственной Фармакопеи Украины: количественное содержание действующих веществ, внешний вид раствора, прозрачность, pH. Результаты и обсуждение. В результате исследования стабильности образцов ветеринарного препарата при хранении со следующими соотношениями действующих веществ: серебра цитрата - 0,01 г, L-aргинина - 0,52 г, декспантенола - 0,50 г установлено, что в условиях долгосрочного хранения в образцах наблюдалась неизменность их фризико-химических свойств в течение 6 месяцев. Результаты ускоренных испытаний обнаружили нестабильность образцов ветеринарного препарата на более ранних сроках, которая может быть следствием деструкции цитрата серебра в исследуемых образцах. Была проведена научно-исследовательская работа с целью изучения стабильности выбранной комбинации действующих веществ после изменении ее концентрации в растворе. Исследование проводили, анализируя результаты наблюдений за стабильностью образцов, полученных двумя способами. По первому способу получали ветеринарную лекарственную фрорму, которая представляет собой два стерильных раствора - А и В, смешивающихся перед введением в одном шприце-тубе для интрамамарного применения. Второй способ отличался тем, что раствор готовили сразу с такими же концентрациями всех компонентов, как в смешанном растворе A + B, при этом сохранялось выбранное соотношение действующих веществ.

Выводы. Подобрано оптимальное соотношение компонентов нового комбинированного интрамамарного препарата антимикробного действия в виде раствора в ампулах, который содержит цитрат серебра - 0,005 г, D пантенол - 0,260 г и L - аргинин - 0,250 г для лечения и профилактики субклинического мастита КРС под условным названием «Аргоцид», который стабилен при хранении в течение 12 месяцев.

Ключевые слова: ветеринарный препарат; интрацистернальное введение; стабильность; цитрат серебра.

ISSN 2312-0967. Фармацевтичний часопис. 2017. № 4 


\title{
SELECTION OF QUANTITATIVE COMPOSITION FOR THE DEVELOPMENT OF THE VETERINARY PREPARATION FOR INTRAMAMMARY INTRODUCTION
}

\author{
Zh. M. Polova ${ }^{1}$, L. H. Almakayeva ${ }^{2}$ \\ O. Bohomolets National Medical University ${ }^{1}$, Kyiv \\ National University of Pharmacy², Kharkiv \\ zpolova@ukr.net
}

The aim of the work. Development of qualitative composition and selection of the optimal ratio of the components of the combined veterinary drug for intramammary administration.

Materials and Methods. The study object was a series of preparations of the antimicrobial action "Argocide", which containing silver citrate, D-panthenol and L-arginine and is intended for the treatment and prevention of subclinical mastitis in cattle. Physico-chemical stability parameters of the preparation were studied at a temperature of $25 \pm 2{ }^{\circ} \mathrm{C}$ for long-term tests and at a temperature of $40 \pm 2^{\circ} \mathrm{C}$ for accelerated tests; defined the following parameters in accordance with the requirements of the State Pharmacopoeia of Ukraine: the quantitative content of active substances, the appearance of the solution, transparency, $\mathrm{pH}$.

Results and Discussion. As a result of the study of stability samples of the veterinary drug during storage with the following proportions of active substances: silver citrate $-0.01 \mathrm{~g}$, L-arginine $-0.52 \mathrm{~g}$, dexpanthenol $-0.50 \mathrm{~g}$, it was found that, under long-term storage conditions, physical and chemical properties for 6 months did not change. The results of the accelerated tests revealed the instability of samples of the veterinary drug at earlier times, which may be a consequence of the destruction of silver citrate in the test samples. A research work was carried out to study the stability of the selected combination of active substances after changing its concentration in solution. The study was carried out by analyzing the results of observations of the stability of samples obtained by two methods. According to the first method, a veterinary dosage form was obtained, which is two sterile solutions - A and B, which are mixed before administration in a single syringe tube for intramammary use. The second method was different in that the solution was prepared immediately with the same concentrations of all components as in a mixed solution of $A+B$, with the selected ratio of active substances being the same.

Conclusions. The optimal ratio of the components of a new combination intramammary preparation of antimicrobial action in the form of a solution in ampoules containing silver citrate $0.005 \mathrm{~g}$, D-panthenol $0.260 \mathrm{~g}$, and L-arginine $0.250 \mathrm{~g}$ for the treatment and prophylaxis of subclinical mastitis of cattle under the code name "Argocid", which is stable during storage for 12 months.

Key words: veterinary drug; intramammary administration; stability; silver citrate.

\section{Список літератури}

1. Технологія виробництва продукції тваринництва [Бусенко О. Т., Скоцик В. Є., Маценко М. І.]. - К. : «Агроосвіта», 2013. - 492 с.

2. Weese J. S. ACVIM consensus statement on therapeutic antimicrobial use in animals and antimicrobial resistance / J. S. Weese, S. Giguere, L.Guardabassi [et al.] // J. Vet. Intern. Med. - 2015. - Vol. 29 (2). P. 487-498.

3. Панченко А. А. Новый подход к лечению мастита у коров [Электронный ресурс] / А. А. Панченко, М.П.Загорулько, Л. Г. Войтенко // Молодежный научный форум: Естественные и медицинские науки. - 2014. - № 10 (16) - С. 18-28. - Режим доступа: http://www.nauchforum.ru/ archive/MNF_nature/10(16).pdf.

4. Абдессемед Д. Диагностика и терапия субликлинического мастита у лактирующих коров / Д. Абдессемед, А. В. Авдеенко // Вестник Саратовского госагроуниверситета им. Н. И. Вавилова. - 2014. - № 3. - С. 3-6.

5. Зимников В. И. Фармако-токсикологическая характеристика нового противомаститного препарата Мастицеср / В. И. Зимников, Н. Т. Климов, Г. А. Востроилова // Зоотехния. - 2011. - № 2. - С. 28-29.

6. Ветеринарне акушерство, гінекологія та біотехнологія відтворення тварин з основами андрології / [В. А. Яблонський, С. П. Хомін, Г. М. Калиновський та ін.]. - Вінниця : Нова книга, 2006. - 592 с.

7. Фармацевтична хімія / [П. О. Безуглий, І. В. Українець, С. Г. Таран та ін.]. - Харків : Золоті сторінки, 2002. - 448 с. 8. Державна фрармакопея України: в 3 т. // Державне підприємство «Український науковий експертний фрармакопейний центр якості лікарських засобів». - 2-е вид. - Харків : Державне підприємство «Український науковий експертний фрармакопейний центр якості лікарських засобів», 2015. - Т. 1. - 1128 с.

9. Настанова 42-3.3:2004. Настанови з якості: Лікарські засоби. Випробування стабільності / Георгієвський В., Ляпунов М., Безугла О. [та ін.] - Київ : МОЗ України, 2004. -60 c.

10. Методичні рекомендації щодо основних правил належної практики виробництва та контролю якості ветеринарних препаратів. - [Електронний ресурс]. - Режим доступу: http://www.vet.gov.ua/node/1819.

11. Commission Directive 91/412/EEC of 23 July 1991 laying down the principles and guidelines of good manufacturing practice for veterinary medicinal products // Official

ISSN 2312-0967. Pharmaceutical review. 2017. № 4 
Фармацевтична технологія, біофармація, гомеопатія Pharmaceutical technology, biopharmacy, homeopathy

Journal of the European Communities L 228. - Brussels, 1991. P. $70-73$.

12. Electronic Medicines Compendium (eMC) [Electronic source] - Available at: www.resourceclinical.com/parenteral-drug-ther

13. Лекарственные средства в ветеринарной медицине / А. И. Ятусевич, Н. Г. Толкач, И. А. Ятусевич, Е. А. Панковец. - М. : Техноперспектива. 2006. - 406 с. 14. Технология и стандартизация лекарств: [в 2 т. ] Под ред. В. П. Георгиевского, Ф.А.Конева. - Харьков Рирег, 2000. - Т. 2. - 781с.

\section{References}

1. Busenko OT, Skotsyk VYe, Matsenko MI. Technology of products animal husbandry [Технологія виробництва продукції тваринництва] Kyiv: Ahroosvita; 2013. Ukrainian. 2. Weese JS, Giguère S, Guardabassi L, Morley PS, Papich M, Ricciuto DR, Sykes JE. ACVIM consensus statement on therapeutic antimicrobial use in animals and antimicrobial resistance. J Vet Intern Med. 2015;29(2): 487-98. Available from: http://dx.doi.org/ DOI:10.1111/jvim.12562.

3. Panchenko AA, Zagorulko MP, Voytenko LG. A new approach to the treatment of mastitis in cows. In: Youth Scientific Forum: Natural and Medical Sciences. 2014;10(16): 18-28. Available from: http://www.nauchforum.ru/archive/ MNF_nature/10(16).pdf. Russian.

4. Abdessemed D, Avdeenko AV. [Diagnosis and therapy of subclinical mastitis in lactating cows]. Vest Sarat Gos Un-ta im NI Vavilova. 2014;3: 3-6. Russian.

5. Zimnikov VI, Klimov NT, Vostroilova GA. [Pharmacological and toxicological characteristics of the new anti-mastitis drug Masticef]. Zootechn.2010;2: 28-9. Russian.

6. Yablonskyi VA, Khomin SP, Kalynovskyi HM, Kharuha $\mathrm{HH}$, Kharenko MI, Zaviriukha VI, Liubetskyi VY. Veterinary obstetrics, gynecology and biotechnology of reproduction of animals with the basics of andrology. [Ветеринарне акушерство, гінекологія та біотехнологія відтворення тварин з основами андрологіï]. Vinnytsia: Nova knyha; 2006. Ukrainian.

7. Bezuhlyi PO, Ukrainets IV, Taran SH. Pharmaceutica chemistry. [Фармацевтична хімія] Kharkiv: National University of Pharmacy; 2002. Ukrainian.

8. State Pharmacopoeia of Ukraine: in 3 vol. / State Enterprise "Ukrainian Research Center expert pharmacopoeia quality medicines." - 2nd ed. - Kharkiv State Enterprise "Ukrainian Research Center expert pharmacopoeia drug
15. Виробництво ампул медичного призначення. Повідомлення 1. / Т. М. Буднікова., В. С. Гульпа, О. П. Шматенко, Л. Г. Алмакаєва // Фармацев. журн. 2004. - № 4. - С. 34 - 40.

16. Фармацевтическая технология: технология лекарственных фрорм / И. И. Краснюк, Г.В.Михайлова, С. А. Валевко. - М. : Academia. 2004. - 592 с.

17. Настанова 42-4.2:2011. Настанови з якості: Лікарські засоби. Управління ризиками для якості (ICH Q9) / Ляпунов М., , Безугла О. [та ін.]. - Київ : МОЗ України, 2011. -26 c.

quality," 2015;1: 1128. Ukrainian

9. Heorhiievskyi V, Liapunov M, Bezuhla O. Guidelines 423.3: 2004. Guidelines for quality: Medicines. Stability test. Kyiv: MOZ Ukrainy, 2004. Ukrainian.

10. Metodychni rekomendatsii shchodo osnovnykh pravyl nalezhnoi praktyky vyrobnytstva ta kontroliu yakosti veterynarnykh preparativ [Methodological recommendations on the basic rules of good manufacturing practice and quality control of veterinary drugs]. Available at: http://www.vet. gov.ua/node/1819.

11. Commission Directive 91/412/EEC of 23 July 1991 laying down the principles and guidelines of good manufacturing practice for veterinary medicinal products. $\mathrm{J}$ of the Eur Com L 228. 1991; 70-3.

12. Electronic Medicines Compendium (eMC) Available at: www.resourceclinical.com/parenteral-drug-ther.

13. Yatusevich AI, Tolkach NG, Yatusevich IA, Pankovets EA. Medical preparation in veterinary medicine. [Лекарственные средства в ветеринарной медицине] Moscow: Tekhnoperspektiva; 2006. Russian.

14. Georgievskiy VP, Konev FA. Technology and standardization of medicines. [Технология и стандартизация лекарств] Kharkov: Rireg 2000. Russian.

15. Budnikova TM., Hulpa VS, Shmatenko OP, Almakayeva LG. [Production of ampoules for medical purposes]. Pharm Journ. 2004;4: 34-40. Ukrainian.

16. Krasnyuk II, Mikhaylova GV, Valevko SA. Pharmaceutical technology: Technology of dosage forms. [Фармацевтическая технология: Технология лекарственных фрорм] Moscow: Academia; 2004. Russian.

17. Guidelines 42-4.2: 2011. Guidelines for quality: Medicines. Quality Risk Management ( $\mathrm{ICH}$ Q9). Kyiv: MOZ Ukrainy, 2011. Ukrainian. 